\title{
PROPERTIES OF CEMENT PASTE AND CONCRETE CONTAINING CALCIUM CARBIDE WASTE AS ADDITIVE
}

\author{
E. N. Ogork ${ }^{1, *}$ and T. S. Ibrahim ${ }^{2}$ \\ 1 Department of Civil EngineERING, Bayero University, PMB 3011 Kano, Kano State, NiGERIA. \\ 2 Nigerian Building ANd RoAd Research Institute, Plot 499 SAMuel OgEDEngBe Crescent, JABi, Abuja NigERIA \\ E-mail addresses: ${ }^{1}$ egbenguogork@yahoo.com, 2 somibraheem@gmail.com
}

\begin{abstract}
This paper assessed the effect of calcium carbide waste (CCW) as additive on the properties of cement paste and concrete. The CCW used was sourced from a local panel beating workshop. It was sundried and sieved through a $75 \mu \mathrm{m}$ sieve and characterized by X-Ray Fluorescence (XRF) analytical method. The consistency, setting times and drying linear shrinkage of cement paste with CCW addition of $0,0.25,0.5,0.75$ and $1.0 \%$, respectively by weight of cement were investigated in accordance with standard procedures. The slump values of fresh concrete containing CCW as additive and of 1:2:4 mix ratio and water-cement ratio of 0.5 was determined. A total of sixty numbers of $150 \mathrm{~mm}$ cubes of hardened concrete were tested for compressive strength at 1, 3, 7, 28 and 56 days of curing in accordance with standard procedures. The concrete compressive strength was also modeled using Minitab statistical software based on linear regression technique. The results of the investigations showed that CCW was predominantly of calcium oxide (95.69\%) and a combined $\mathrm{SiO}_{2}, \mathrm{Al}_{2} \mathrm{O}_{3}$ and $\mathrm{Fe}_{2} \mathrm{O}_{3}$ content of $3.14 \%$. The addition of CCW in cement decreased drying shrinkage (100 $\%)$, initial setting time (78\%) and final setting time (57\%), but increased consistency (14\%) at $1.0 \%$ CCW content. The addition of CCW in concrete also showed slight increase in slump (6.5\%) and increase in compressive strength with increase in CCW additive up to $0.5 \%$ and decrease in compressive strength with further increase in CCW content. The 28 days compressive strength of concrete with $0.5 \%$ CCW content was $6.4 \%$ more than normal, while that of concrete with $1.0 \%$ CCW content was $14.9 \%$ less than normal. The compressive strength model of CCW-concrete was developed with $R^{2}$ value of 0.830 and could be used to predict concrete compressive strength.
\end{abstract}

Keywords: Additive, cement paste, concrete, Calcium carbide waste, Compressive strength model

\section{INTRODUCTION}

The possibility of incorporating wastes from industrial or agricultural processes in the construction industry is borne out of the need to provide sustainable materials for construction. This is achieved either by searching for or incorporating new materials and products that are more environmental friendly and/or contributing towards the reduction of carbon dioxide emission into the atmosphere [1,2]. Research trends in materials development have also focused on providing alternatives necessitated by the high cost of conventional materials, difficulties in accessing fund for construction/ building development, amongst many other reasons. The alternatives to conventional materials include use of pozzolanas as substitutes to cement or as mineral admixtures and use of other binders from agricultural wastes and by-products from industrial processes as admixtures or additives. In many developing countries the demand for building construction materials such as
Ordinary Portland cement and admixtures is high to meet the infrastructure needs of the citizens. However, the production of these products requires capital intensive plants and expertise, with consequent high cost in addition to increase in the prices of traditional building materials to the common man due to inflation. To reduce the cost of material and construction to affordable rate, many research works have been directed towards utilization of cheap and readily available local materials such as industrial and agricultural by -products as substitute of aggregate or binder in infrastructure construction $[3,4]$.

The use of additive or admixtures in concrete is necessary in situations where there is a need to enhance the properties of either fresh or hardened concrete or both for a particular purpose. In most situations the realization of such improvement can only be achieved effectively and more rapidly when appropriate additives are used. According to [5], chemical admixtures are 
added to concrete in small doses, often not more than 1 $\%$ by weight of cement, while mineral admixtures are introduced in larger doses, up to $5 \%$ by weight of cement.

There is abundant literature on use of conventional admixtures in concrete. Research on use of local materials such as agricultural waste and by-products from industrial processes as admixtures is still growing. Many research works on use of local waste materials as admixtures in concrete have been conducted from universities and other tertiary institutions in Nigeria and most developing countries. However, the research findings have remained unexplored for these admixtures to be used in construction works. This may be due to the weak link between academic research and the industry for large scale production, amongst other reasons.

A few of the researches on local waste materials as admixtures in concrete include; Poliostigma Thonningii fruit powder which can act as accelerator and strength improving agent in concrete for doses up to $0.5 \%$ by weight of cement [6]. Dye residue ash of up to $5.0 \%$ by weight of cement was also reported to slightly improve concrete workability and enhances strength and durability [7]. According to [8] and [9], rice husk ash when used as additive at doses of up to $5.0 \%$ by weight of cement improved workability and compressive strength of concrete, but the durability of the concrete was impaired. Researches by [10] and [11] indicated that cocoa pod husk ash at doses of up to $0.6 \%$ by weight of cement acted as a retarder, improved workability, enhanced compressive strength and durability of concrete. In another research, sawdust ash in additions of up to $2.0 \%$ by weight of cement increased setting time, enhanced compressive strength and durability of concrete [12]. Groundnut shell ash in additions of up to $4.0 \%$ by weight of cement was also reported to have increased setting time, compressive strength and resistance to sulphuric acid [4]. It was also reported by [13] that cassava peel powder as additive for doses up to $0.6 \%$ by weight of cement increased setting time, workability and compressive strength of concrete, just to mention a few.

According to [14], calcium carbide waste (CCW) is a byproduct obtained from the acetylene gas $\left(\mathrm{C}_{2} \mathrm{H}_{2}\right)$ production process as shown in equation (1).

$$
\mathrm{CaC} 2+2 \mathrm{H}_{2} \mathrm{O} \rightarrow \mathrm{C}_{2} \mathrm{H}_{2}+\mathrm{Ca}(\mathrm{OH})_{2}
$$

Acetylene gas is widely used for ripening fruits in agriculture and for welding in industry [2]. In Nigeria and most developing countries, the acetylene gas is used for welding in local panel beating workshops across the cities. The by-product (CCW) is often discarded as waste and dumped in landfills and this poses a threat to the environment. CCW is mainly composed of calcium hydroxide and is mainly alkaline, with $\mathrm{pH}$ greater than
12 [2]. In order to reduce environmental pollution, attempts have been made to use CCW in more useful ways, especially in the building industry. Research findings such as that of [15] have indicated that CCW, when combined with certain pozzolanas such as fly ash, silica fume, etc, containing high silicon dioxide and aluminium oxide could due to pozzolanic reactions yield final products that are similar to those obtained from cement hydration process. More researches are still being conducted on use of CCW in construction.

It is against this background that this research sets out to investigate the use of CCW as an additive in cement paste and concrete. This may be a cheaper alternative to conventional admixtures, which may lead to reduction in the cost of construction. This may also be a means of addressing the environmental pollution caused by the accumulation of the waste.

\section{MATERIALS AND METHODS \\ 2.1 Materials}

Sand was obtained from River Watari in Kano, Nigeria. The particle size distribution curve of the sand is shown in Figure 1. The coarse aggregate is crushed granite of nominal size of $20 \mathrm{~mm}$. The particle size distribution curve is also shown in Figure 1. The physical properties of the materials are shown in Table 1. Ordinary Portland cement (Ashaka brand) was used. The oxide composition of the cement is shown in Table 2. Calcium carbide waste (CCW) was sourced from a local panel beating workshop in Kano, Nigeria. The CCW was sundried and sieved through a $75 \mu \mathrm{m}$ sieve. Chemical composition analysis of the CCW was conducted using X-Ray Fluorescence (XRF) analytical method and the results are shown in Table 2.

\subsection{Methods}

\subsubsection{Tests on cement paste}

Five mixes were used for the determination of consistency and setting times of cement paste containing CCW in accordance with [16]. MP-00 is the control mix and MP-01, MP-02, MP-03 and MP-04 are mixes containing CCW additions of $0.25,0.5,0.75$ and $1.0 \%$, respectively. Average of three readings was recorded. The dry linear shrinkage of the cement paste was determined using prism specimens of $40 \mathrm{~mm}$ x $40 \mathrm{~mm}$ x $140 \mathrm{~mm}$. The shrinkage was determined in accordance with [17].

\subsubsection{Concrete mix proportion}

Concrete mix of 1:2:4 and water-cement ratio of 0.5 was used to assess the effect of CCW as additive in concrete in the order as stated above. 


\subsubsection{Slump and compressive strength of concrete with CCW additives}

Workability of fresh concrete with CCW addition was determined in accordance with [18] using the mixes stated above. The compressive strength of concrete with CCW additive was carried out in accordance with [19] for the concrete mix of 1:2:4 and water-cement ratio 0.5 . A total of sixty (60 Nos) $150 \mathrm{~mm}$ cube specimens were cast and cured in water for 3, 7, 28 and 56 days. At the end of every curing time, compressive strength was determined in accordance with [19].

\subsubsection{Statistical modeling of CCW-concrete mixtures}

Statistical model was developed from experimental data using MINITAB 11 software to predict compressive strength of concrete containing CCW. In developing the compressive strength predictive model of the CCWconcrete, two effects were considered; (i) influence of CCW content and (ii) influence of curing. The software generates model equations and graphs that would best fit the experimental data. A comparison is then made between the experimental data and data generated by the models and the error difference evaluated.

\section{DISCUSSION OF RESULTS}

\subsection{Physical Properties of Concrete Constituent Materials}

The physical properties of the constituent materials are shown in Table 1, while the particle size distribution curves are shown in Figure 1. The grain size curve indicates that the sand used was classified as zone 2 based on British Standard classification [20] grading limits for fine aggregates and was well graded.

\subsection{Cement and Calcium Carbide Waste}

The oxide composition of calcium carbide waste (CCW) (Table 2) indicated that it was predominantly CaO (95.69
\%) and low combined $\mathrm{SiO}_{2}, \mathrm{Al}_{2} \mathrm{O}_{3}$ and $\mathrm{Fe}_{2} \mathrm{O}_{3}$ content of $3.14 \%$. This shows that CCW is cementitious and may combined with certain pozzolanas containing high silicon dioxide and aluminium oxide in a hydrated mix and due to pozzolanic reactions yield final products that are similar to those obtained from cement hydration process [15]. The chemical composition of the cement is satisfactory and has met the standard [21].

\subsection{Calcium Carbide Waste-Cement Pastes}

Normal consistency of cement with addition of CCW increases with increase in CCW content as shown in Figure 2. The consistency of paste with $1.0 \%$ CCW content as additive increased by $14 \%$ of normal. More water is required for wetting the particles as the total surface area of the particle is increased [22]. Furthermore, since CCW has a less specific gravity than the OPC, a large volume of water may be required to properly wet excess volume of CCW added to the mix to produce CCW-cement gel and this could lead to increase in consistency of the CCW-cement paste, consistent with [23]. The setting times of CCW-cement decreased with increase in CCW content as shown in Figure 3. The initial and final setting time of paste with $1.0 \% \mathrm{CCW}$ content decreased by $78 \%$ and $57 \%$ of normal, respectively.

Table 1: Physical properties of constituent materials

\begin{tabular}{lcccc}
\hline Property & Cement & Sand & $\begin{array}{c}\text { Crushed } \\
\text { granite }\end{array}$ & CCW \\
\hline $\begin{array}{l}\text { Specific gravity } \\
\begin{array}{l}\text { Bulk density } \\
\left(\mathrm{kg} / \mathrm{m}^{3}\right)\end{array}\end{array}$ & 3.14 & 2.55 & 2.65 & 2.04 \\
$\begin{array}{l}\text { Moisture content } \\
(\%)\end{array}$ & - & 1630.0 & 1562.0 & - \\
\hline
\end{tabular}

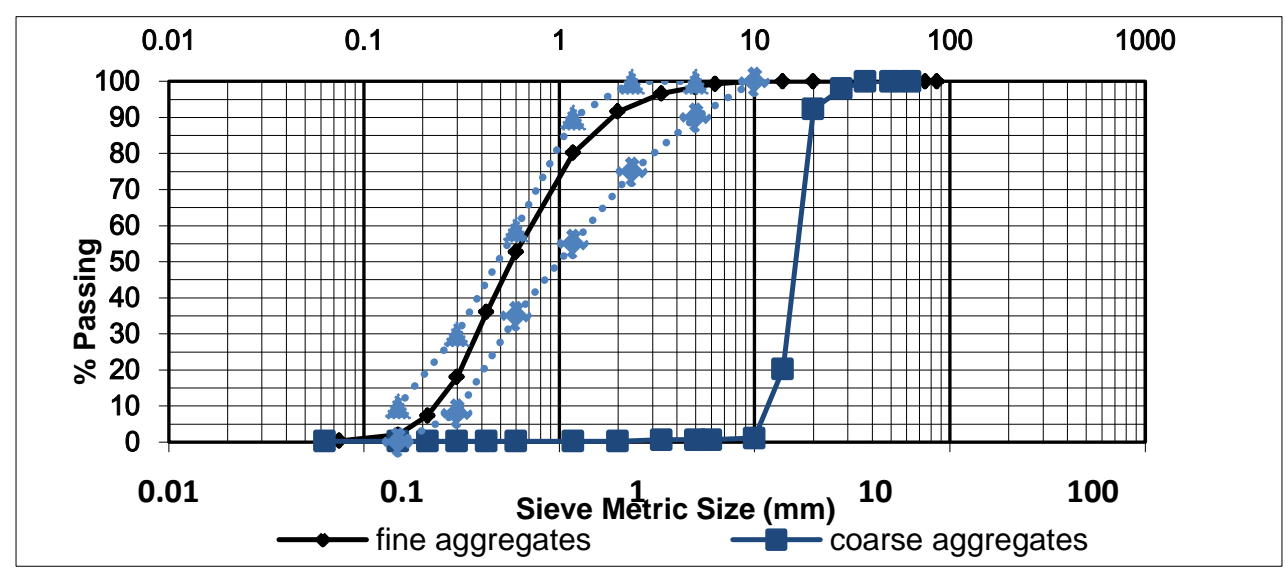

Figure 1: Particle size distribution of River sand and coarse aggregate 
Table 2: Oxide composition of OPC (Ashaka brand) and CCW

\begin{tabular}{llllllllllll}
\hline Oxide (\%) & $\mathrm{SiO}_{2}$ & $\mathrm{Al}_{2} \mathrm{O}_{3}$ & $\mathrm{Fe}_{2} \mathrm{O}_{3}$ & $\mathrm{CaO}$ & $\mathrm{MgO}$ & $\mathrm{K}_{2} \mathrm{O}$ & $\mathrm{Na}_{2} \mathrm{O}$ & $\mathrm{SO}_{3}$ & $\mathrm{TiO}_{2}$ & $\mathrm{BaO}$ & $\mathrm{L} . \mathrm{o} . \mathrm{I}$ \\
\hline OPC & 18.0 & 3.10 & 4.80 & 67.34 & 1.48 & 0.35 & 0.32 & 1.82 & 0.35 & 0.16 & 1.30 \\
$\mathrm{CCW}$ & 2.1 & 0.50 & 0.54 & 95.69 & - & 0.47 & - & 0.31 & - & 0.09 & \\
\hline
\end{tabular}

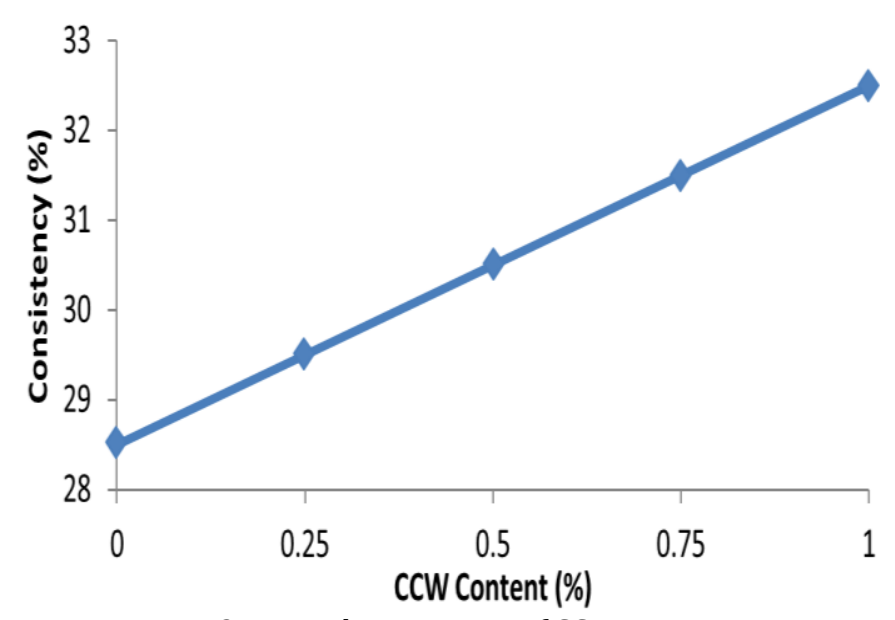

Figure 2: Normal consistency of CCW-cement paste

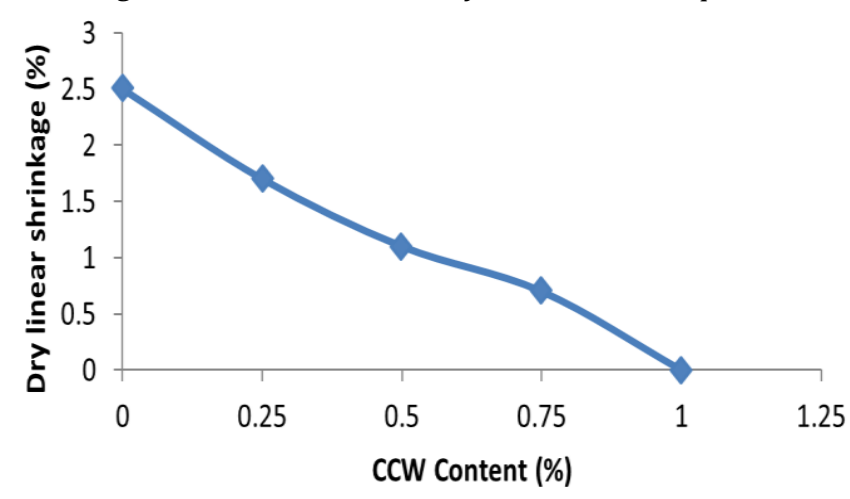

Figure 4: Drying shrinkage of CCW-cement paste

This behavior may be due to additional reaction activity of calcium carbide waste, as the silica and alumina react with calcium hydroxide to form additional calcium silicate and calcium aluminate and may result in quick setting [24]. It was observed that the initial setting time of CCW-cement paste with CCW content of up to $0.5 \%$ satisfied the [21] requirement of initial setting time not less than 45 minutes.

The drying shrinkage of CCW-Cement paste shows a decrease in linear drying shrinkage with percentage addition of CCW as shown in Figure 4. The linear drying shrinkage of paste with $1.0 \%$ CCW content as additive decreased by $100 \%$ of normal. This may be due to the high content of calcium oxide in CCW which hydrates and reduces the water content, and this indicated that the concrete can be used in a cold weather condition and may not crack since increase in percentage addition of CCW reduces linear shrinkage of the concrete [12].

\subsection{Slump of CCW-Concrete}

The slump of concrete containing CCW is slightly higher than that of OPC concrete as shown in Figure 5. The
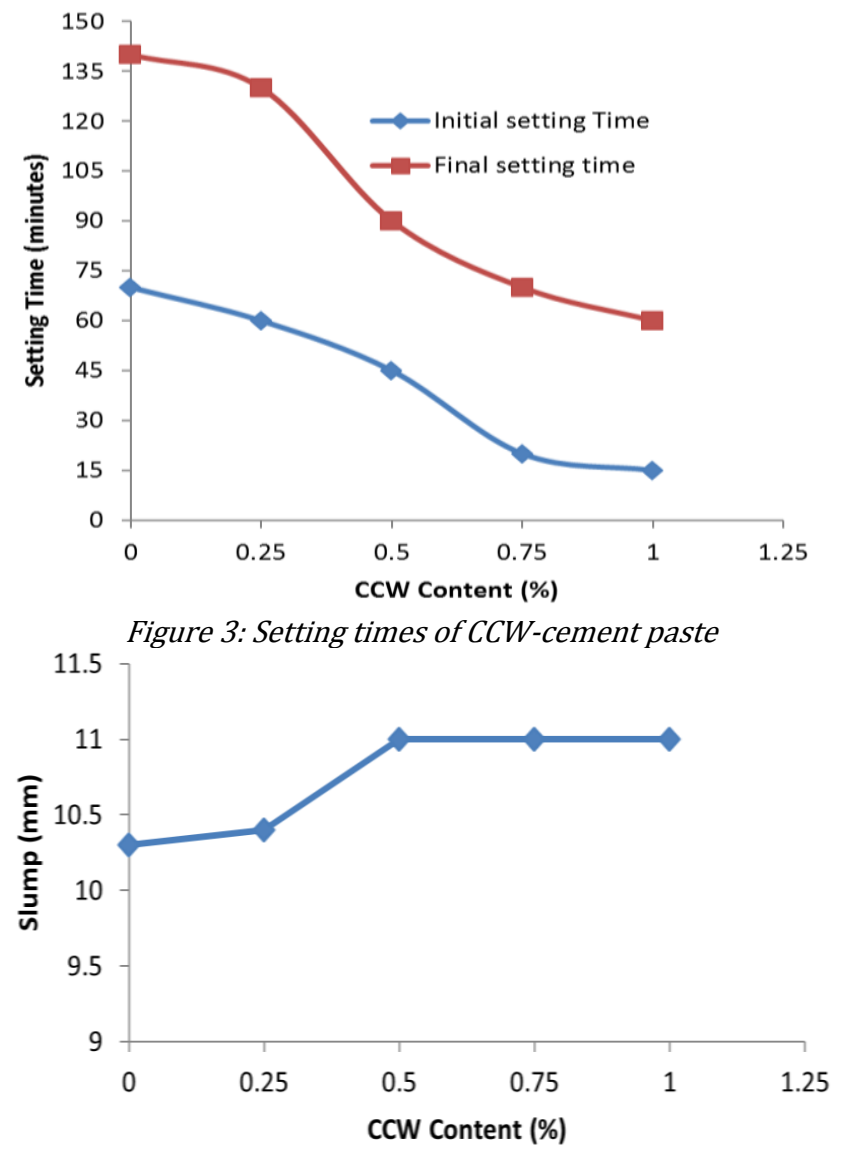

Figure 5: Slump of CCW-concrete

slight increase in slump (6.5\% more than normal) may be due to the particle packing effect of CCW responsible for the reduced water demand in plasticizing the system [25].

\subsection{Compressive strength of CCW-Concrete}

The compressive strength of CCW-concrete showed that compressive strength increased with curing age and also increased with addition of up to $0.5 \%$ of CCW. Further increase in addition of CCW showed a decrease in compressive strength of the concrete as shown in Figure 6. The 28 days compressive strength of concrete with 0.5 $\%$ CCW content was $6.4 \%$ more than normal, while that of concrete with $1.0 \% \mathrm{CCW}$ content was $14.9 \%$ less than normal. The increase in compression strength with curing age is due to hydration of cement and CCW, while increase in compressive strength with addition of CCW up to $0.5 \%$ may be due to formation of additional calcium silicate hydrates from the hydration of CCW. The reduction in compressive strength with addition of CCW of $0.75 \%$ and above may be due to saturation of the cement mix with oxides of $\mathrm{CaO}$ from $\mathrm{CCW}$ which may 
inhibit the formation of strength giving calcium silicate hydrates from cement hydration, consistent with [26] report on sawdust ash in concrete.

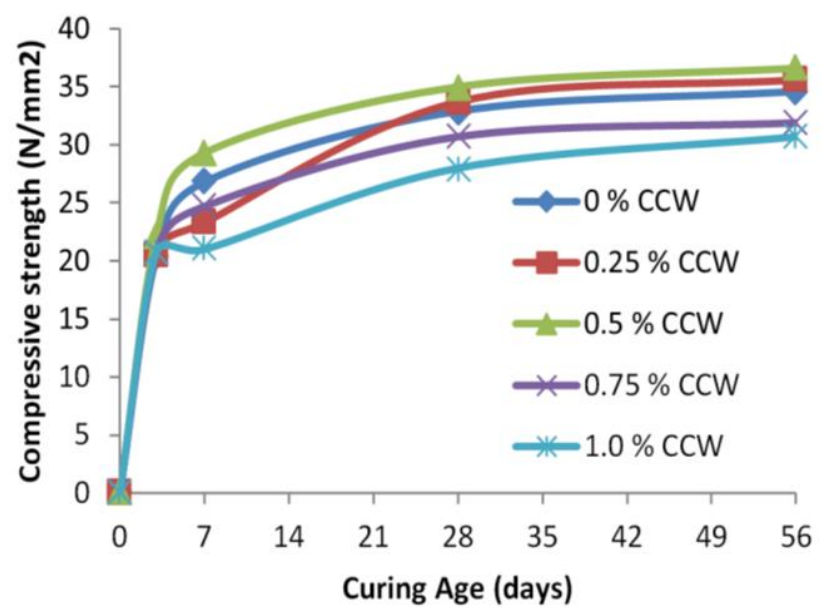

Figure 6: Compressive strength development of CCWconcrete.

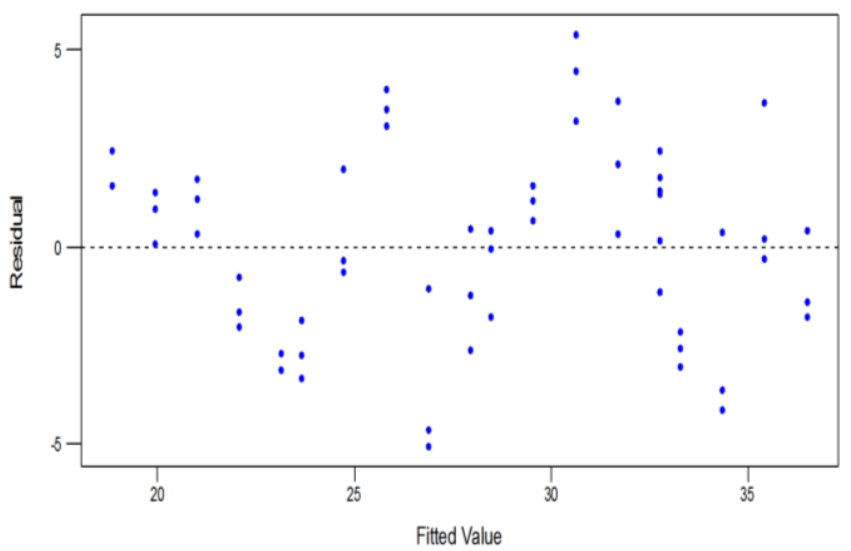

Figure 7: Residual versus fitted values for compressive strength of CCW-concrete

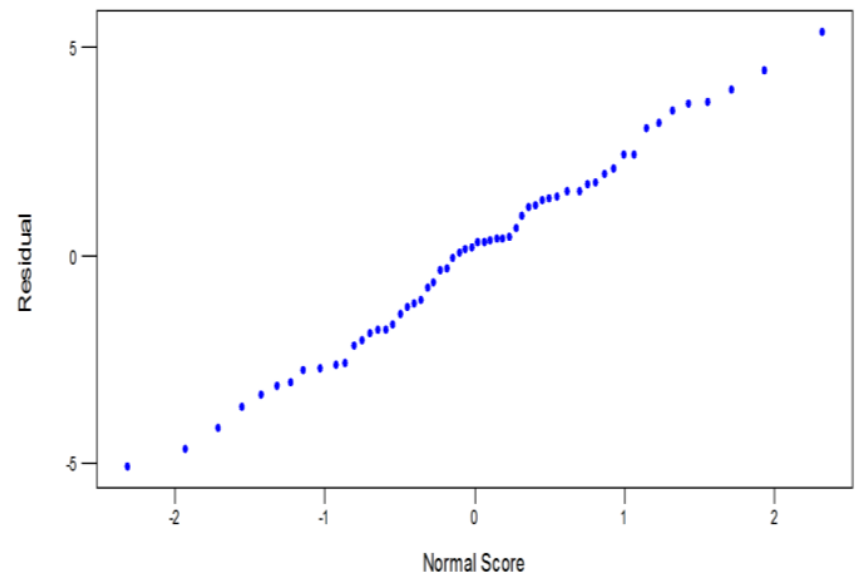

Figure 8: Normal probability of residuals for compressive strength of $C C W$-concrete

\subsection{Regression Model for CCW Modified Concrete Compressive Strength}

The regression equation generated for compressive strength of CCW-concrete model is given in equation (2).

$$
\mathrm{f}_{\mathrm{cc}}=19.40-1.107 \mathrm{X}_{1}+4.81 \mathrm{X}_{2}
$$

Where; $\mathrm{f}_{\mathrm{cc}}$ is the concrete compressive strength, $\mathrm{X}_{1}$ is the $\%$ CCW at $0,0.25,0.5,0.75$ and $1.0 \% \mathrm{X}_{2}$ is the curing age of samples at 3, 7, 28 and 56 days.

At $5 \%$ level of significance, from the regression analysis, $\mathrm{P}$-value $=0.000$ for both CCW content and age of curing of concrete, respectively and shows that both variables are significant $(\mathrm{P}<0.05)$ signifying that the variation in the concrete compressive strength is caused by CCW content and age of curing. The coefficient of determination, $\left(\mathrm{R}^{2}\right)$ is $83.0 \%$ and indicates that the variation of concrete strengths is significantly dependent on the variations of CCW content and age of curing. The residual and normality plots (Figure 7 and 8) were drawn for the compressive strength of concrete to further examine how well the model fits the data used. It was observed that there were few large residuals and limited apparent outlier, consistent with works of [26, 27 , and 28]. This confirms that the model is adequate for design prediction.

\section{CONCLUSIONS}

i) Calcium carbide waste (CCW) is predominantly of $\mathrm{CaO}$ (95.69\%).

ii) Calcium carbide waste addition increased the consistency, but decreased drying shrinkage and setting times of cement paste, and could be used as an accelerator.

iii) CCW addition also slightly increased the workability of concrete.

iv) The addition of up to $0.5 \%$ CCW increased the compressive strength of concrete.

v) The compressive strength model of CCW-concrete with $\mathrm{R}^{2}$ value of 0.830 could be used to predict concrete strength.

\section{REFERENCES}

[1] Hardjito, D., Antoni, Wibowo, G. M., Christtianto, D. "Pozzolanic activity assessment of LUSI (Lumpur SIdoarjo) mud in semi high volume pozzolanic mortar", Materials, Vol. 5, pp 1654-1660. 2012.

[2] Sun, H., Li, Z., Bai, J., Memon, S. A., Dong, B., Fang, Y., Xu, W. and Xing, F. "Properties of chemically combusted calcium carbide residue and its influence on cement properties", Materials, vol. 8, pp 638-651 2015.

[3] Elinwa, A. U., Ejeh, S. P. and Akpabio, I. O. "Using metakaolin to improve sawdust ash concrete", Concrete International, Vol. 27, Number 11, pp 49-52. 2005.

[4] Wazumtu, M. and Ogork, E. N. "Assessment of groundnut shell ash (GSA) as admixture in cement paste and concrete", International Journal of Innovative Science, Engineering and Technology, Vol. 2, Issue 2, pp 77-86 2015 ,

[5] Neville, A. M. Properties of concrete, fourth edition. Pearson Education, Singapore, 2003. 
[6] Ogork, E. N. and Rimi, M. K. "Kargo (Poliostigma thonningii) fruits powder as admixture in concrete", Journal of Engineering and Technology, Vol. 2, number 1, pp 9-15 2007.

[7] Ogork, E. N. and Koko, N.M.S. "Katsi (Dye residue ash) as admixture in concrete", Journal of Engineering and Technology, Vol. 5, number 1, pp 81-89. 2010.

[8] Aboshio, A., Ogork, E. N. and Balami, D. A. "Rice husk ash as admixture in concrete", Journal of Engineering and Technology, Vol. 4, number 2, pp 97-103 2009.

[9] Ogork, E. N., Aboshio, A. and Balami, D. A. "Durability assessment of concrete made with rice husk ash as admixture", Journal of Engineering and Technology, Vol. 5, number 1, pp 90-98 2010.

[10] Audu, V. E. M. and Mamman, Y. W. "Use of cocoa pod husk ash as admixture in concrete", International Journal of Engineering Research and Technology, Vol. 2, number 11, pp 3781-3793, 2013.

[11] Ogork, E. N. and Audu, V. E. M. "Cocoa pod husk ash (CPHA) concrete in aggressive environment", Journal of Engineering and Technology, vol. 10, number 1, 2015, pp $35-43$

[12] Ogork, E. N. and Ayuba, S. "Influence of sawdust ash (SDA) as admixture in cement paste and concrete", International Journal of Innovative Science, Engineering and Technology, Vol. 1, Issue 10, 2014, pp 736-743

[13] Ogork, E. N. and Araga, A. O. "Potentials of cassava peel powder (CPP) as admixture in concrete", Journal of Engineering and Technology, Vol. 10, number 1, 2015, pp 7-15

[14] Makaratat, N., Jaturapitakkul, C., Namarak, C. and Sata, V. "Effects of binder and $\mathrm{CaCl}_{2}$ contents on the strength of calcium carbide residue - fly ash concrete", Cement Concrete Composites, vol. 33, 2011, pp 436-443

[15] Wang, Y. L., Dong, S. J., Liu, L. L. and Ciu, S. P. "Using calcium carbide slag as one of calcium containing raw materials to produce cement clinker", Energy Environ. Mater., Vol. 171, pp 743-744. 2013.

[16] BS EN 196, Part 3: Methods of testing cement: Determination of setting time and soundness, British Standard Institution, London, 1995
[17] BS 4550, Part B: Method for determination of linear shrinkage for concrete, Her Majesty Stationary Office, London, 1978.

[18] BS EN 12350, Part 2: Slump test, British Standard Institution, London, 2009

[19] BS EN 12390, Part 3: Method for determination of compressive strength of concrete cubes, British Standard Institution, London, 2009

[20] BS 882, Part 2: Grading limits for fine aggregates, British Standard Institution, London, 1992

[21] BS EN 197, Part 1: Composition, specification and conformity criteria for common cements, British Standard Institution, London, 2000

[22] Marthong, C. "Size effect study of sawdust ash-concrete under compressive load", Journal of Mechanical and Civil Engineering, Vol. 1, Issue 5, pp 27-32. 2012.

[23] Ettu, L. O., Nwachukwu, K. C. and Arimawa, C. T. G. "Variation of strength of OPC-sawdust ash cement composites with water-cement ratio", International Journal of Engineering and Science (IRJES), vol. 2, pp 09132013

[24] Bjorn, M. and Katinka, S. Alumina-based castables with very low contents of hydraulic compound. Paper presented at UNITECK, Kyoto, Japan. Part 1, pp 3. 1995

[25] Mehta, P. K. High performance, high volume fly ash concrete for sustainable development. In: Proceedings of the International workshop on sustainable development and concrete Technology, University of California, Berkeley, U.S.A., 2004.

[26] Elinwa, A. U. and Abdulkadir, S. "Characterizing sawdust ash for used as an inhibitor for reinforcement corrosion", New Clues in Science, vol. 1, pp 1-10 2011,

[27] Field, A. Discovering statistics using SPSS for windows. Sage publication London. United Kingdom, pp 492 2002,

[28] Razak, H. A. and Wong, H.S. "Strength estimation model for high-strength concrete incorporating metakaolin and silica fume", Cement and Concrete Research, vol. 35, pp 688-695. 2004 